\title{
K-Ar DATING OF AMPHIBOLES FROM ANDESITE OF COMPLEX DYKE IN DUBIE (SOUTHERN POLAND)
}

\author{
ANNA LEWANDOWSKA ${ }^{1}$, MICHAL BANAŚ ${ }^{2}$ and KAROLINA ZYGOŃ ${ }^{1}$ \\ ${ }^{1}$ Institute of Geological Sciences, Jagiellonian University, \\ Oleandry 2a, 30-063 Cracow, Poland \\ ${ }^{2}$ Institute of Geological Sciences, Polish Academy of Sciences, \\ Senacka 1, 31-002 Cracow, Poland
}

Received 20 February 2007

Accepted 22 March 2007

\begin{abstract}
This study presents the results of radiometric K-Ar measurements on separated amphiboles from the andesite of the Dubie complex dyke. The data obtained cover the period of (291.3 \pm 6.4$) \mathrm{Ma}$, which corresponds to Carboniferous-Permian transition. The age is contemporaneous to the rhyodacitic and basaltoid volcanism of the Kraków region.
\end{abstract}

Keywords: K-Ar dating, amphiboles, andesite, Permian, Carboniferous

\section{INTRODUCTION}

At the north-eastern border of the Upper Silesian Coal Basin, magmatic rocks occur along Myszków-ZawiercieKraków zone which is a part of the major, transcontinental, Hamburg-Kraków fault zone (HKFZ) (Żaba, 2000; Fig. 1). In this zone, late Palaeozoic magmatism (Jarmołowicz-Szulc, 1984 and 1985; Harańczyk, 1989; Podemski, 2001) comprises large granodiorite intrusions, rhyodacite laccoliths and domes, basaltoid lava extrusions with associated pyroclastic rocks, and small dykes and sills of diabases, andesites, dacites, rhyodacites, rhyolites and minor lamprophyres (Muszyński, 1995 and works cited therein; Czerny and Muszyński, 1997; Lewandowska and Rospondek, 2003).

Among the minor intrusions an example of intermediate rocks is present: an andesite from a complex dyke outcropping in the Dubie quarry located near Krzeszowice, about $20 \mathrm{~km}$ north-west of Kraków (Fig. 1). The andesitic dyke cuts through Devonian (Givetian) dolomites of the Dębnik brachyanticline. The brachyanticline owes its form to the rhyodacite laccolith, which uplifted and metamorphosed Devonian and early Carboniferous carbonate rocks (Bogacz, 1980; Lewandowska, 1991).

The dyke is up to $3 \mathrm{~m}$ wide and can be traced along

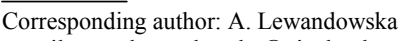

e-mail: anna.lewandowska@uj.edu.pl

ISSN 1897-1695 (online) (C) 2007 GADAM Centre,

Institute of Physics, Silesian University of Technology.

All rights reserved. a distance of about $500 \mathrm{~m}$ in the Dubie quarry (Fig. 2). Clear zonation, perpendicular to its walls, suggests that the magma passage opened several times. The black andesite builds the central part, while grey-green dacite forms the outer part (Harańczyk and Wala, 1989; Muszyński and Pieczka, 1992). Several centimetres of argilitic rocks are encountered at the interface with the wall rocks, presumably being products of hydrothermal alternation of the volcanic rock (Harańczyk and Chłopecka, 1989). The black andesite is thought to mark the initial stage of the passage opening (Harańczyk, 1982; Harańczyk and Wala, 1989). This variety of andesite reaches about $0.5 \mathrm{~m}$ of width.

Geochemically, rocks of the dyke were classified as calc-alkaline andesites and dacites (Muszyński and Pieczka, 1992; Muszyński, 1995, Czerny and Muszyński, 1997) using the classification of Peccarillo and Taylor (1976).

The early Permian age of volcanism of the Kraków area was determined based on the superposition of the volcanic rocks in relation to the palaeontologically dated Karniowice travertine (Lipiarski, 1970). A few geochronological studies of felsic volcanic and plutonic rocks of the region point to the transition between Carboniferous and Permian (Skowroński, 1974; Harańczyk, 1989). In addition, the paleomagnetic data on rhyodacites from Zalas confirm the early Permian age of the felsic rocks (Nawrocki et al., 2005). However, the age of intermediate volcanics has not been determined so far. 


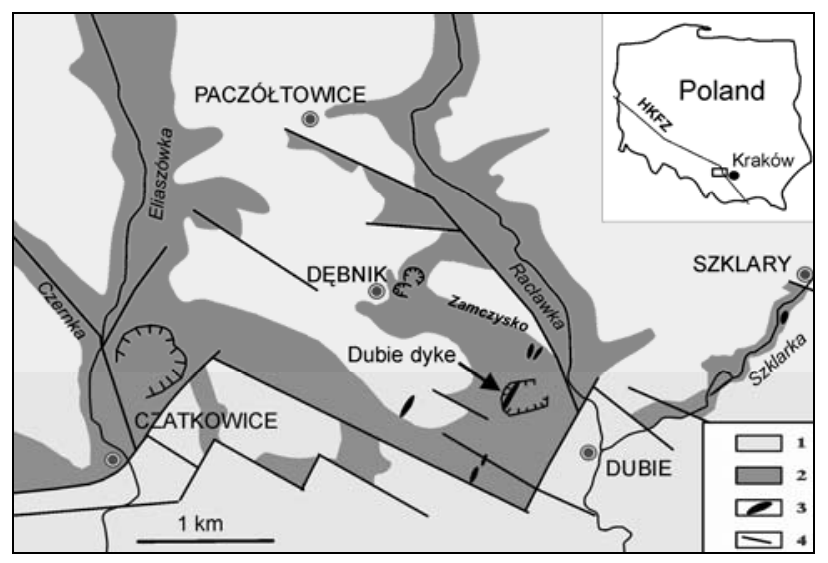

Fig. 1. Simplified geological map of the area of investigations: 1. Mesozoic sediments; 2. Carboniferous and Devonian limestones and dolomites; 3. Late Paleozoic volcanic rocks; 4. Faults (according to Kozłowski, 1955 and Łaptaś, 1982); HKFZ Hamburg-Kraków fault zone.

This study presents the first dating of andesites of the Kraków region and aims to shed light on chronological constrains of volcanic events.

\section{METHODOLOGY}

Representative samples were collected from different zones of the dyke in Dubie quarry. For detailed studies the samples from the inner andesitic part of a dyke were selected. Unfortunately, the exploitation progress in the Dubie quarry led to the consumption of a huge part of a dyke in 2005 year, most of contemporary collected samples carry the signs of alteration. Therefore for K-Ar studies the unique sample DW38, from the Jagiellonian University museum collection was chosen. This sample was collected in 70's by A. Wala.

A Nikon Eclipse E600 POL polarising microscope quipped with cathodoluminescence and LUCIA Measurement software for image analyses were used for petrographical observations. Mineralogical investigations were based on the X-ray diffraction analysis using an APD Philips diffractometer with $\mathrm{CuK}_{\alpha}$ radiation over an angular range of $4-64^{\circ} 2 \Theta$ with X'Pert Philips analytical software. A field-emission scanning electron microscope HITACHI SEM S-4700 coupled with an energy depressive spectrometer (EDS) with a NORAN VANTAGE analytical system and a back-scattered electron image detector were used for chemical composition analyses of separated crystals.

\section{Amphiboles separation.}

The sample of black andesite was crushed by hammering, pulverized in a mortar and sieved. Clay minerals were removed by multiple water washing; this procedure was followed by carbonate removal in acetate acetic buffer. Amphiboles were separated from the fraction below $500 \mu \mathrm{m}$. The residual heavy minerals were separated in heavy liquid $\left(\rho=3 \mathrm{~g} / \mathrm{cm}^{3}\right)$. The light fraction consisted mainly of feldspars and quartz. The heavy fraction was additionally subdivided into three groups using

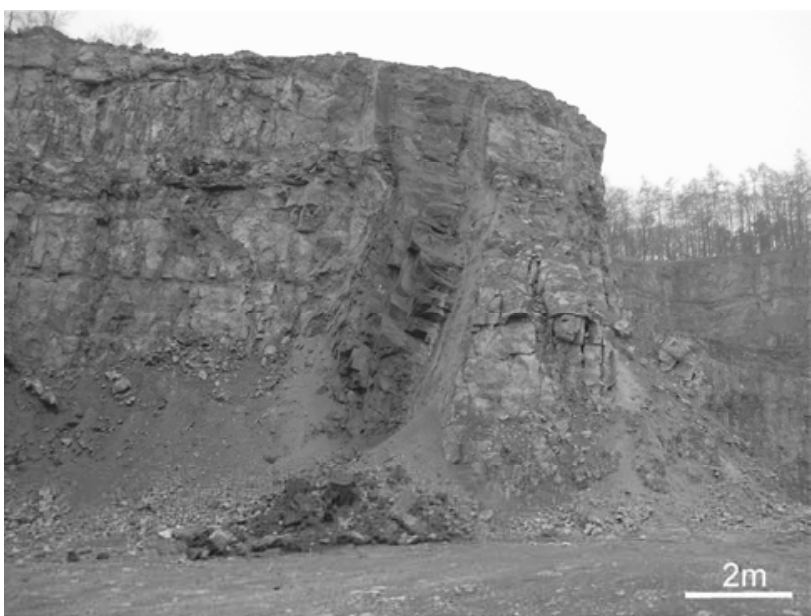

Fig. 2. The andesitic dyke in Dubie quarry in 2004 (exploitation level is $340 \mathrm{~m}$ above sea level).

a neodymium magnet. The first group of ferromagnetic minerals was attracted by the magnet from a distance of about $0.8 \mathrm{~mm}$ (these were mainly iron-titanium oxides). The second group was attracted by the magnet in the direct contact and these were mainly amphiboles subsequently used in the age determination. The remnant third group of grains consisted of agglomerates of amphiboles, Fe-Ti oxides and plagioclases.

\section{K-Ar age determination.}

The monomineral amphibole sample was split into two aliquots: a $100 \mathrm{mg}$ one for potassium determination and $150 \mathrm{mg}$ one for argon analysis. The $100 \mathrm{mg}$ sample was diluted in a mixture of $\mathrm{HF}$ and $\mathrm{H}_{2} \mathrm{SO}_{4}$. The solution was evaporated in a steam bath and once more diluted in $\mathrm{HCl}(1: 1)$. The potassium content was determined with the use of a spectrophotometer Sherwood 420. During the measurements international standard „Cordobamuscovite" was used to test the procedure. The analytical error was $0.02 \% \mathrm{~K}_{2} \mathrm{O}$.

The isotopic composition of Ar was determined by the extraction method (details in Bonhomme et al., 1975) using an MS20 mass spectrometer. The sample was fused in a Ti-Ta crucible by resistance heating (Durakiewicz, 1995 ) and the released gas was purified on $\mathrm{Ti}$ and $\mathrm{Zr}-\mathrm{Al}$ getters (Fig. 3). The analytical precision was periodically controlled by the measurements of the radiogenic ${ }^{40} \mathrm{Ar}$ content of the international standard GLO. The mean content of six determinations made previously and during the analysis was $(24.99 \pm 0.48(2 \delta)) \times 10^{-6} \mathrm{~cm}^{3} / \mathrm{g}$ STP being well in the range of the accepted values: $(24.85 \pm 0.50)$ (Odin et al., 1982). The overall precision of the K-Ar age determinations which were calculated using the decay constant recommended by Steiger and Jaeger (1977) was better than $\pm 2 \%$.

\section{RESULTS}

The Dubie andesite is a porphyritic rock with light plagioclase and black amphibole phenocrysts set in aphanitic black groundmass. The phenocrysts assemblage, apart of plagioclase and amphibole crystals consists of 


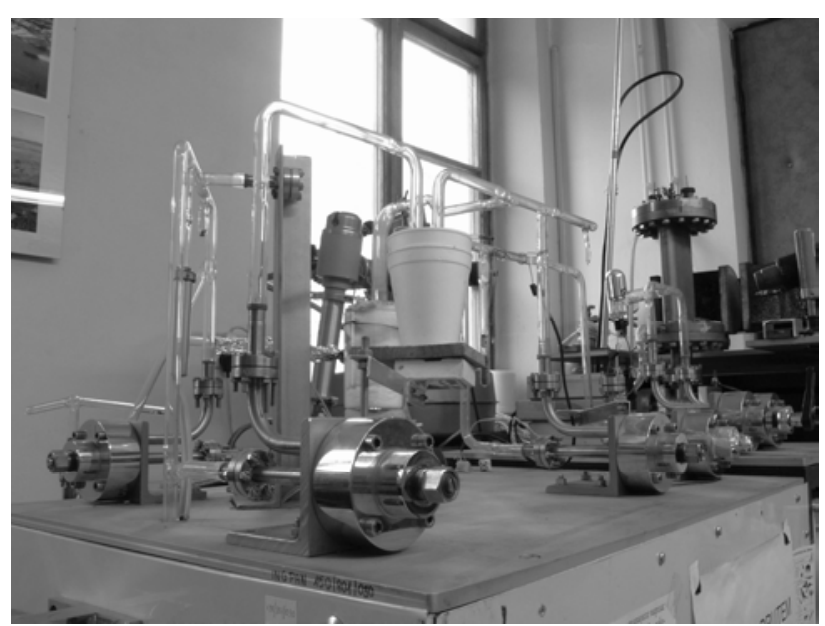

Fig. 3. The mass spectrometer and purification line for $A r^{*}$ (radiogenic Ar) measurements.

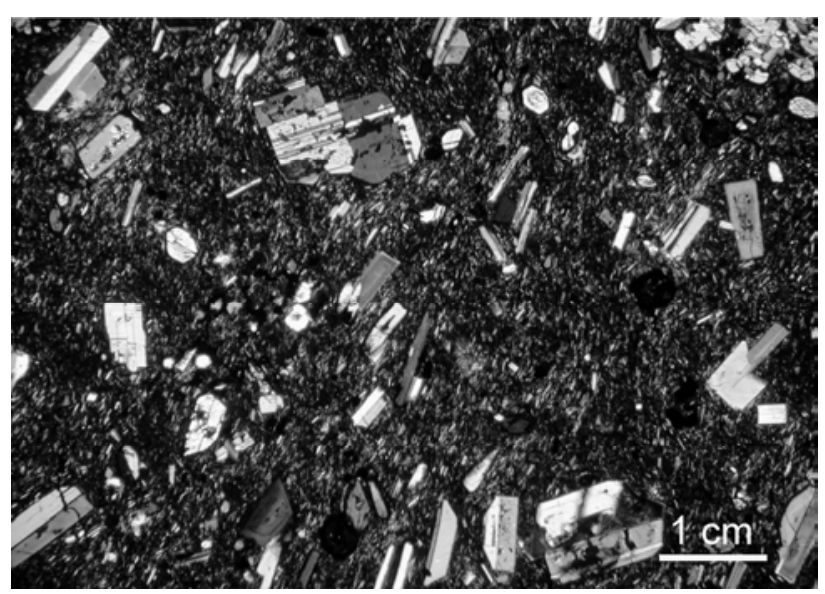

Fig. 4. Dubie andesite with zoned, twinned plagioclase phenocrysts and smaller amphibole phenocrysts set in a fine crystalline plagioclase matrix (petrographic microscope, crossed polars).

rare biotite flakes. The idiomorphic and hypidiomorphic plagioclase phenocrysts are abundant and have about $5-8 \mathrm{~mm}$ in size, sporadically reaching $2 \mathrm{~cm}$. In plagioclases concentric reverse zoning (labrador - An 50 to $70 \%$ ) and polysynthetic twinning are common (Fig. 4). Amphibole phenocrysts are represented by idiomorphic prisms up to $0.5 \mathrm{~mm}$ in size, they show olive to brown pleochroism and are surrounded by fine opacite reaction rims (Figs 5 and 6). The idiomorphic form of amphibole crystals and lack of other than Fe-Ti oxides inclusions indicate that amphiboles were among the first crystallising phases in the Dubie andesite. The rare biotite flakes reach $5 \mathrm{~mm}$ in size. The aphanitic matrix is composed of euhedral plagioclase laths (andesine An 35 - $50 \%$ ), intergrown in an irregular fashion to form felty texture and volcanic glass altered to clay minerals. Accessory minerals assemblage consists of opaque minerals, represented mainly by iron-titanium oxides and apatite needles.

The amphibole microanalyses recalculations (mean of six) give its formulae as $\left(\mathrm{Na}_{0.44} \mathrm{~K}_{0.09}\right) \mathrm{Ca}_{1.91}$ $\left(\mathrm{Mg}_{2.55} \mathrm{Fe}_{2.09} \mathrm{Al}_{0.21} \mathrm{Ti}_{0.25}\right) \quad\left[\mathrm{Si}_{6.69} \mathrm{Al}_{1.31}\right] \mathrm{O}_{22}(\mathrm{OH})_{2}$. Such a composition straddles the borders among magnesiohornblende, tschermakite and magnesio-alumino sadana-
Table 1. XRD powder data for DW38 AM sample (separated amphibole fraction) compared to JCPD data.

\begin{tabular}{|c|c|c|c|c|}
\hline \multicolumn{5}{|c|}{ Saple DW38 AM } \\
\hline 2Theta & $d(\AA)$ & intensity & $\begin{array}{c}\text { Magnesio- } \\
\text { Hornblende } \\
\text { JCPDS21-0149 }\end{array}$ & $\begin{array}{c}\text { Ferro- } \\
\text { Tschermakite } \\
\text { JCPDS43-0665 }\end{array}$ \\
\hline 63.09 & 1.472 & 3 & & 1.48 \\
\hline 61.62 & 1.503 & 8 & & 1.50 \\
\hline 61.36 & 1.509 & 6 & & 1.51 \\
\hline 60.84 & 1.521 & 5 & & 1.525 \\
\hline 60.08 & 1.538 & 5 & & 1.536 \\
\hline 59.25 & 1.558 & 4 & & 1.555 \\
\hline 58.05 & 1.587 & 10 & 1.592 & 1.581 \\
\hline 56.66 & 1.623 & 5 & 1.625 & 1.622 \\
\hline 56.02 & 1.640 & 4 & & 1.637 \\
\hline 55.49 & 1.654 & 14 & 1.656 & 1.649 \\
\hline 54.46 & 1.683 & 2 & & 1.683 \\
\hline 54.08 & 1.694 & 4 & & 1.695 \\
\hline 53.21 & 1.719 & 5 & & 1.700 \\
\hline 52.13 & 1.752 & 1 & & 1.752 \\
\hline 50.15 & 1.817 & 5 & & 1.811 \\
\hline 48.67 & 1.869 & 5 & & 1.868 \\
\hline 48.01 & 1.893 & 7 & 1.900 & 1.880 \\
\hline 45.98 & 1.972 & 2 & & 2.002 \\
\hline 44.77 & 2.022 & 13 & 2.025 & 2.025 \\
\hline 44.09 & 2.051 & 6 & 2.054 & 2.051 \\
\hline 41.55 & 2.171 & 16 & 2.172 & 2.179 \\
\hline 40.30 & 2.235 & 2 & & 2.227 \\
\hline 39.31 & 2.289 & 5 & & 2.292 \\
\hline 38.59 & 2.330 & 11 & 2.337 & 2.322 \\
\hline 38.32 & 2.346 & 19 & 2.351 & 2.342 \\
\hline 37.59 & 2.390 & 7 & 2.388 & 2.381 \\
\hline 35.07 & 2.555 & 16 & 2.558 & 2.557 \\
\hline 34.39 & 2.605 & 17 & 2.606 & 2.604 \\
\hline 32.90 & 2.720 & 39 & 2.720 & 2.715 \\
\hline 32.59 & 2.744 & 27 & 2.750 & 2.738 \\
\hline 31.81 & 2.810 & 13 & 2.818 & 2.800 \\
\hline 30.29 & 2.948 & 17 & 2.953 & 2.941 \\
\hline 28.5 & 3.13 & 100 & 3.14 & 3.11 \\
\hline 27.6 & 3.23 & 5 & & 3.27 \\
\hline 27.1 & 3.29 & 31 & 3.29 & 3.27 \\
\hline 26.2 & 3.40 & 19 & 3.40 & 3.39 \\
\hline 23.7 & 3.75 & 3 & $?$ & $?$ \\
\hline 22.7 & 3.90 & 4 & & 3.90 \\
\hline 21.8 & 4.07 & 5 & $?$ & $?$ \\
\hline 21.0 & 4.22 & 4 & 4.23 & $?$ \\
\hline 19.5 & 4.55 & 8 & 4.55 & 4.53 \\
\hline 18.6 & 4.77 & 2 & & 4.74 \\
\hline 18.0 & 4.93 & 3 & & 4.92 \\
\hline 17.3 & 5.12 & 2 & & 5.09 \\
\hline 10.4 & 8.52 & 60 & 8.51 & 8.40 \\
\hline 9.6 & 9.16 & 6 & 9.15 & 9.05 \\
\hline
\end{tabular}

gaite fields, on the diagram showing the compositional variations of the calcium amphiboles (Hawthorne and Oberti, 2006). This identification is in agreement with the $\mathrm{X}$-ray diffraction pattern (Table 1), where the amphibole 


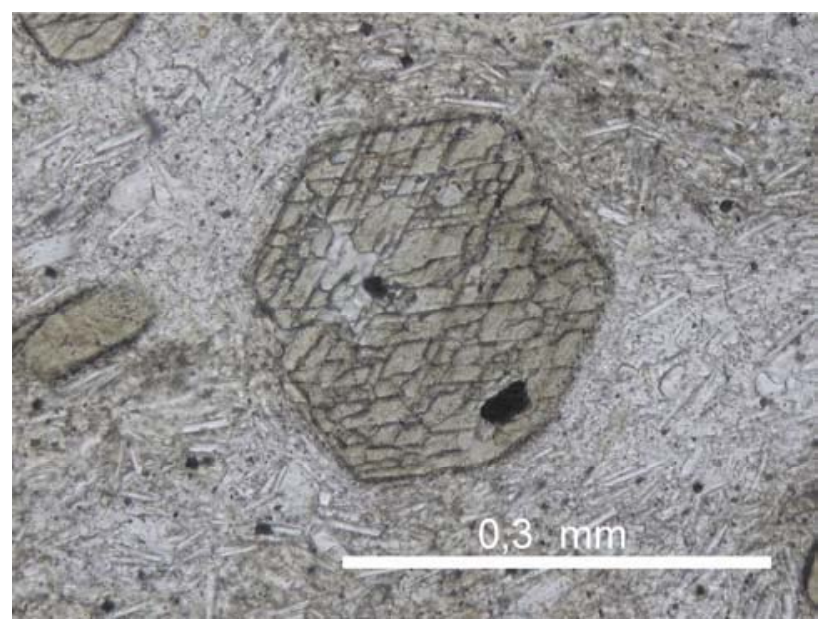

Fig. 5. Amphibole phenocryst with thin opacite rim from DW38 sample (plane polarised light).

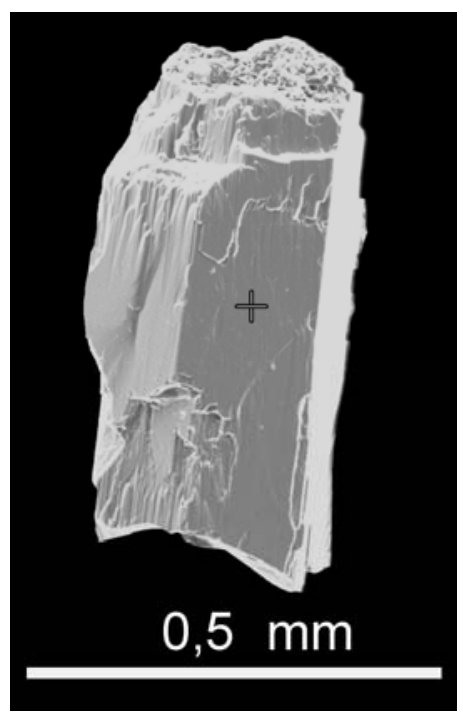

Fig. 6. SEM image of separated amphibole crystal.

main reflexes are like those of the reference magnesiohornblende (JCPDS21-0149) and slightly diverge from those of ferro-tschermakite (JCPDS43-0665). This determination is also consistent with the previous identification of amphibole as magnesio-hornblende (Muszyński and Pieczka, 1992).

Although potassium content in amphibole is minor, ca. 0.44 wt. $\% \mathrm{~K}_{2} \mathrm{O}$ (Table 2), its presence allowed the $\mathrm{K}$-Ar age determination. The $\mathrm{K}_{2} \mathrm{O}$ content 0.44 wt. $\%$ and ${ }^{40} \mathrm{Ar} *$ content $50.1 \%$ correspond to the closing age of amphiboles (291.3 \pm 6.4$)$ Ma (Table 2).

\section{DISCUSSION}

The K-Ar amphibole age of $(291.3 \pm 6.4)$ Ma of the Dubie andesite, obtained in this study indicates that it is contemporaneous to the other volcanic activities in the Kraków region. Dating of the felsic volcanism of the nearby Myszków area, based on K-Ar biotite and the whole rock analyses (Jarmołowicz-Szulc, 1984 and 1985) gave $(301 \pm 29) \mathrm{Ma}$. In the range of the analytical error, it fits the Zalas rhyodacite age of $295 \mathrm{Ma}$ (tracks in biotite) (Skowroński, 1974). The singular Ar-Ar date of basaltic
Table 2. The results of K-Ar measurements of amphibole from andesite from Dubie.

\begin{tabular}{lcccccc}
\hline Sample & Mineral & $\begin{array}{c}\mathrm{K}_{2} \mathrm{O} \\
(\%)\end{array}$ & $\begin{array}{c}{ }^{40} \mathrm{Ar}^{*} \\
(\%)\end{array}$ & $\begin{array}{c}{ }^{40} \mathrm{Ar}^{*} \\
(\mathbf{p m o l} / \mathrm{g})\end{array}$ & $\begin{array}{c}\text { Age } \\
(\mathrm{Ma})\end{array}$ & $\begin{array}{c}\text { Error } \\
(\mathrm{Ma})\end{array}$ \\
\hline DW38AM & Amphibole & 0.44 & 50.1 & 200.2 & 291.3 & 6.4 \\
\hline${ }^{40} \mathrm{Ar}{ }^{*}$ - radiogenic ${ }^{40} \mathrm{Ar}$ & & & & &
\end{tabular}

rocks from the region was $305 \mathrm{Ma}$ and concerned the biotite age from the Myszków diabase (Podemski, 2001). Although limited precision of the K-Ar method does not allow to assign the time of andesite formation in chronological order with respect to other rhyodacitoid or basaltoid volcanism of the region, the field observations show that the rhyodacitic laccolith, which formed the Dębnik brachyanticline, had intruded and solidified before the Dubie andesitic dyke formation. This was deduced from the composition of the volcanic breccia uplifted by andesitic magma, which contained rhyodacite fragments in the grain framework (Harańczyk, 1982 and 1989; Harańczyk and Wala, 1989).

The almost contemporaneous time of andesitic, rhyodacitic and basaltoid volcanism in the Kraków region is concordant with the observations of contemporary volcanic environments, which show that one volcano can produce magmas from basic to acid compositions within short periods (e.g. Sigurdsson and Sparks, 1981).

The volcanic rocks of the Kraków region carry signs of later, post magmatic alteration processes like $\mathrm{K}$-metasomatosis and feldspatization described from the Zalas rhyodacite (Słaby, 2000; Nawrocki et al., 2005). The mineralogical evidences show that the Dubie complex dyke formation was followed by hydrothermal activity, which resulted in alteration of the dyke rocks and clay minerals formation (Harańczyk and Chłopecka, 1989). Planned K-Ar age measurements on illites from the outer zones of the dyke will probably clarify the timing of postmagmatic processes.

\section{CONCLUSION}

The K-Ar dating of amphiboles separated from the andesite from the Dubie complex dyke $(291.3 \pm 6.4) \mathrm{Ma}$ corresponds to Carboniferous-Permian transition. It is contemporaneous to the other Variscan volcanic activity of the Kraków region.

\section{ACKNOWLEDGEMENTS}

Authors cordially thank to Mr. Antoni Wala for the donation of unique samples and to Mrs. Dorota Bakowska for $\mathrm{K}_{2} \mathrm{O}$ measurements. The text highly benefited from the reviewer remarks. The study was partly supported by funds of the scientific research project N30702231/1746 in the years 2006-2008 and the DS funds of Jagiellonian University.

\section{REFERENCES}

Bogacz K, 1980. Budowa geologiczna paleozoiku dębnickiego (Geological structure of Palaeozoic of Dębnik). Rocznik Polskiego Towarzystwa Geologicznego 50: 183-208 (in Polish). 
Bonhomme MG, Thuizat R, Pinault Y, Clauer N, Wendling R. and Winkler R, 1975. Me'thode de datation potassium - argon. Appareillage et Technique (The potassium - argon dating method). Notes technique de l'Institut de Ge'ologie, Universite' Louis Pasteur, Strasbourg 3: 53 pp.

Durakiewicz T, 1995. Innowacje w aparaturze do wydzielania i oczyszczania argonu (Innovations in the apparatus for argon separation and purifiction). II Ogólnopolska Sesja Naukowa. Datowanie minerałów i skat: 38-44 (in Polish).

Czerny J and Muszyński M, 1997. Co-magmatism of the Permian volcanities of the Krzeszowice Area in the light of petrochemical data. Mineralogia Polonica 28 (2): 3-25.

Harańczyk C, 1982. Magmatyzm okolic Dubia (The magmatism of the Dubie area). Przewodnik LIV Zjazdu Polskiego Towarzystwa Geoleologicznego: 124-127 (in Polish).

Harańczyk C, 1989. Rozwój wulkanizmu krakowskiego (The development of the Kraków area volcanism). Przewodnik LX Zjazdu Polskiego Towarzystwa Geoleologicznego: 51-57 (in Polish).

Harańczyk C and Chłopecka A, 1989. Przeobrażenia skał komina andezytowego w Dubiu (The alterations of andesitic chimney in Dubie). Przeglad Geologiczny 37: 332-334 (in Polish).

Harańczyk C and Wala A, 1989. Andezytowy komin wulkaniczny w Dubiu (The andesitic volcanic chimney in Dubie). Przewodnik $L X$ Zjazdu Polskiego Towarzystwa Geologicznego: 67-71 (in Polish).

Hawthorne FC and Oberti R, 2006. On the classification of amphiboles. The Canadian Mineralogist, Journal of the Mineralogical Association of Canada 44: 1-21.

Jarmołowicz-Szulc K, 1984. Datowania metodą K-Ar skał NE obrzeżenie Górnoślasskiego Zagłębia Weglowego (K-Ar dating of rocks of the NE edge of the Upper Silesian Coal Basin). Kwartalnik Geologiczny 28: 749-750 (in Polish).

Jarmołowicz-Szulc K, 1985. Badania geochronologiczne K- Ar skał magmowych północno-wschodniego obrzeżenia Górnośląskiego Zagłębia Węglowego (K-Ar geochronological studies of the northeastern edge of the Upper Silesian Coal Basin). Kwartalnik Geologiczny 29 (2): 343-354 (in Polish).

Kozłowski S, 1955. Intruzje porfirowe w grzbiecie Dębnickim (Porphyritic intrusions of the Dębnik Ridge). Biuletyn Instytutu Geologicznego 97: 39-86 (in Polish).

Lewandowska A, 1991. Minerals of the zone of altered Devonian dolomites from Dubie near Kraków (Southern Poland). Mineralogia Polonica 22 (2): 29-40.

Lewandowska A, and Rospondek M, 2003. Geochemistry of volcanics of the Zalas area near Kraków, South Poland. Prace Specjalne Polskiego Towarzystwa Mineralogicznego 23: 119-121.

Lipiarski I, 1970. The Carboniferous-Permian Boundary in the Eastern Part of the Kraków Silesian Coal Basin. Biulletin da L'Academie Polonaise des Sciences 28: 173-178.

Łaptaś A, 1982. Sedymentacja utworów węglanowych dewonu środkowego rejonu Debnika (Sedimentation of the Middle Devonian carbonates of the Dębnik area). Studia Geologica Polonica 75: 59100.

Muszyński M, 1995. Systematic position of igneous rocks from the northern margin of the Upper Silesian Coal Basin. Mineralogia Polonica 26 (1): 33-49.

Muszyński M and Pieczka A, 1992. Hornblende andesites and dacites from Dubie near Krzeszowice. Mineralogia Polonica 23 (1): 43-63 (in Polish).

Nawrocki J, Polechońska O, Lewandowska A and Werner T, 2005. On the palaeomagnetic age of the Zalas laccolith (Southern Poland). Acta Geologica Polonica 55 (3): 229-236.

Odin GS and 35 Collaborators, 1982. Interlaboratory Standards for Dating Purposes. In: Odin GS, ed., Numerical Dating in Stratigraphy. Wiley and Sons, Chichester: 123-149.

Peccarillo A and Taylor SR, 1976. Geochemistry of Eocene calcalcaline volcanic rocks from the Kastamonu area, Northern Turkey. Contributions to Mineralogy and Petrology 58 (1): 63-81.

Podemski M, 2001. Palaeozoic Porphyry Molybdenium-Tungsten Deposit in the Myszków Area, Southern Poland. Polish Geological Institute Special Papers, Państwowy Instytut Geologiczny 6: 1-88.

Sigurdsson H and Sparks RSJ, 1981. Petrology of rhyolitic and mixed magma ejecta from 1875 eruption of Aksja, Iceland. Journal of Petrology 22: 41-84.

Skowroński A, 1974. Oznaczenie wieku bezwzględnego tzw. porfirów z Zalasu metoda śladów rozszczepienia jąder uranu (Track absolute age of so called Zalas porphyry). Sprawozdania z Posiedzeń Komisji Nauk PAN Oddziat w Krakowie 17: 236-237 (in Polish).

Słaby E, 2000. Adularia and albite - hydrothermal feldspars from Zalas and Mięknia rocks. Prace Specjalne Polskiego Towarzystwa Mineralogicznego 17: 94-96.

Steiger RH and Jaeger E, 1977. Subcommission on geochronology: convention on the use of decay constants in geo- and cosmochronology. Earth and Planetary Science Letters 36: 259-262.

Żaba J, 2000. Tectono-magmatic activity of the Upper Silesia terrane and Malopolska terrane edge (Southern Poland). Prace Specjalne Polskiego Towarzystwa Mineralogicznego 17: 81-83. 